\title{
Characterization of Surface Oxide Film Formed on Ti-8Fe-8Ta-4Zr
}

\author{
Daisuke Kuroda ${ }^{1}$, Yuta Tanaka ${ }^{2}$, Hironori Kawasaki ${ }^{2, * 1}$, \\ Katsuhiko Asami ${ }^{3}$ and Takao Hanawa ${ }^{4, * 2}$ \\ ${ }^{1}$ Biomaterials Center, National Institute for Materials Science, Tsukuba 305-0044, Japan \\ ${ }^{2}$ Shibaura Institute of Technology, Minato-ku, Tokyo 108-8548, Japan \\ ${ }^{3}$ Institute of Materials Research, Tohoku University, Sendai 980-8577, Japan \\ ${ }^{4}$ Institute of Biomaterials and Bioengineering, Tokyo Medical and Dental University, Tokyo 101-0062, Japan
}

We have already developed a novel $\beta$-type titanium alloy, $\mathrm{Ti}-8 \mathrm{Fe}-8 \mathrm{Ta}-4 \mathrm{Zr}$, for biomedical applications. Ti-8Fe-8Ta-4Zr showed higher strength than conventional biomedical titanium alloys, such as Ti-6Al-4V ELI, Ti-6Al-7Nb, and Ti-13Nb-13Zr. In addition, the alloy also showed higher corrosion resistance than cp-Ti and Ti-6Al-4V ELI in Hanks' solution. In particular, the breakdown potential of the alloy (the pitting potential) was over $3.5 \mathrm{~V} v$ s. SCE (saturated calomel electrode) and much higher than those of cp-Ti and Ti-6Al-4V ELI. A slightly active region was observed at about $1.7 \mathrm{~V} v s$. SCE that may be related to the high breakdown potential.

In this study, the surface oxide films on $\mathrm{Ti}-8 \mathrm{Fe}-8 \mathrm{Ta}-4 \mathrm{Zr}$ after anodic polarization at 1 and $3 \mathrm{~V}$ in Hanks' solution were characterized using X-ray photoelectron spectroscopy and Auger electron spectroscopy to elucidate the high corrosion resistance mechanism of the alloy in Hanks' solution. In addition, the surface oxide film on the alloy before anodic polarization was also characterized for comparison.

The surface oxide film on Ti-8Fe-8Ta-4Zr is grown with anodic polarization. Calcium phosphate is formed on the alloy after polarization. The corrosion resistance of the alloy after polarization at a potential above $1.7 \mathrm{~V}$ is improved by the concentration of iron and titanium in the surface oxide film. A titanium hyper-oxidized layer with a low iron concentration is observed within the surface oxide film. This layer is generated with polarization and worked as a corrosion-protective layer. The slight active region on the polarization curve may be caused by the dissolution of iron and titanium.

(Received July 14, 2005; Accepted October 17, 2005; Published December 15, 2005)

Keywords: $\beta$-type titanium alloy, corrosion resistance, surface composition, simulated body environment, biomaterial

\section{Introduction}

Beta-type titanium alloys, such as $\mathrm{Ti}-13 \mathrm{Nb}-13 \mathrm{Zr}$, Ti$15 \mathrm{Mo}-5 \mathrm{Zr}-3 \mathrm{Al}$, and $\mathrm{Ti}-\mathrm{Nb}-\mathrm{Ta}-\mathrm{Zr}$ system alloys, which consist of non-toxic elements, have been developed to achieve a lower Young's modulus with high strength because $\mathrm{Ta}, \mathrm{Zr}, \mathrm{Nb}$, and Mo are suitable elements to increase the strength and decrease the Young's modulus of $\beta$-type titanium alloys. ${ }^{1-4)}$ From the viewpoint of material cost, $\mathrm{Ti}-\mathrm{Fe}-\mathrm{Cr}$, Ti-Fe-Mo-Al, and Ti-Fe-V-Al system alloys with a large amount of $\mathrm{Fe}$ have been developed ${ }^{5-8)}$ because $\mathrm{Fe}$ is a low-cost alloying element and an attractive $\beta$ stabilizer for titanium alloys. Therefore, Fe, Ta, and $\mathrm{Zr}$ are the most suitable alloying elements for $\beta$-type titanium alloys to achieve high strength, a low Young's modulus, and low material cost.

For these reasons, $\beta$-type titanium alloys, $\mathrm{Ti}-8 \mathrm{Fe}-8 \mathrm{Ta}$, $\mathrm{Ti}-$ $8 \mathrm{Fe}-8 \mathrm{Ta}-4 \mathrm{Zr}$, and $\mathrm{Ti}-10 \mathrm{Fe}-10 \mathrm{Ta}-4 \mathrm{Zr}$, have been newly designed and developed for biomedical applications. ${ }^{9)}$ Only the $\beta$ phase was identified on the diffraction patterns from these alloys after cold rolling and solution treatment. The tensile strengths of $\mathrm{Ti}-8 \mathrm{Fe}-8 \mathrm{Ta}$ and $\mathrm{Ti}-8 \mathrm{Fe}-8 \mathrm{Ta}-4 \mathrm{Zr}$ solution-treated at 1078 and $1018 \mathrm{~K}$ for $3.6 \mathrm{ks}$ were larger than those of conventional biomedical titanium alloys, such as Ti6Al-4V ELI, Ti-6Al-7Nb, and Ti-13Nb-13Zr, while the elongations to fracture of $\mathrm{Ti}-8 \mathrm{Fe}-8 \mathrm{Ta}$ and $\mathrm{Ti}-8 \mathrm{Fe}-8 \mathrm{Ta}-4 \mathrm{Zr}$ after solution treatment were equal to those of Ti-6Al-4V ELI and Ti-6Al-7Nb after annealing. The corrosion resistance of these alloys was much higher than that of cp-Ti and

\footnotetext{
${ }^{* 1}$ Graduate Student. Present address: Japan Lifeline Co., Ltd., Tokyo 174 0041, Japan

${ }^{* 2}$ Corresponding author. E-mail: hanawa.met@tmd.ac.jp
}

Ti-6Al-4V ELI. In anodic polarization, the corrosion potential of these alloy systems was higher than that of cpTi and lower than that of Ti-6Al-4V ELI in Hanks' solution. The passivation current density of the alloy systems was about $4.5 \times 10^{-6} \mathrm{~A} \mathrm{~cm}^{-2}$ and almost the same as those of cp$\mathrm{Ti}$ and Ti-6Al-4V ELI. In particular, the breakdown potentials of the alloy system (pitting potential) were over $3.5 \mathrm{~V}$ vs. SCE and much higher than those of cp-Ti and Ti6Al-4V ELI. In addition, a slight active region was observed at about $1.7 \mathrm{~V}$ vs. SCE that may be related to the high breakdown potential. Therefore, the corrosion resistance of the new alloy system was high despite the presence of pitting corrosion.

In this study, the surface oxide films on Ti-8Fe-8Ta-4Zr before and after anodic polarization were characterized using X-ray photoelectron spectroscopy (XPS) and Auger electron spectroscopy (AES) to elucidate the high corrosion resistance mechanism of the alloy in Hanks' solution. Ti-8Fe-8Ta-4Zr showed the best balance between strength and elongation after solution treatment in the previous study. Elucidating the mechanism of high corrosion resistance will enhance the understanding of the development of highly corrosionresistant titanium alloys.

\section{Materials and Methods}

\subsection{Specimen preparation}

A button-shape ingot of $\mathrm{Ti}-8 \mathrm{Fe}-8 \mathrm{Ta}-4 \mathrm{Zr}$ in mass $\%$ (Ti7.5Fe-2.3Ta-2.3Zr in at\%) with $100 \mathrm{~g}$ in weight was prepared by the arc-melting process in an argon atmosphere. Table 1 shows the chemical composition of the designed alloy. Plates with $2.5-\mathrm{mm}$ thickness were obtained by hot and cold rolling. Plates were solution-treated at $1018 \mathrm{~K}$ for $3.6 \mathrm{ks}$. 
Table 1 Chemical composition of $\mathrm{Ti}-8 \mathrm{Fe}-8 \mathrm{Ta}-4 \mathrm{Zr}$ in mass $\%$.

\begin{tabular}{cccccccc}
\hline $\mathrm{Fe}$ & $\mathrm{Ta}$ & $\mathrm{Zr}$ & $\mathrm{C}$ & $\mathrm{O}$ & $\mathrm{N}$ & $\mathrm{H}$ & $\mathrm{Ti}$ \\
\hline 7.85 & 8.02 & 3.33 & 0.028 & 0.037 & 0.001 & 0.003 & Bal. \\
\hline
\end{tabular}

Table 2 Ion concentrations of Hanks' solution.

\begin{tabular}{lc}
\hline \multicolumn{1}{c}{ Ion } & Concentration $\left(\mathrm{kmol} \mathrm{m}^{-3}\right)$ \\
\hline $\mathrm{Na}^{+}$ & $1.42 \times 10^{-1}$ \\
$\mathrm{~K}^{2+}$ & $5.81 \times 10^{-3}$ \\
$\mathrm{Mg}^{2+}$ & $8.11 \times 10^{-4}$ \\
$\mathrm{Ca}^{2+}$ & $1.26 \times 10^{-3}$ \\
$\mathrm{Cl}^{-}$ & $1.45 \times 10^{-1}$ \\
$\mathrm{HPO}_{4}{ }^{2-}$ & $7.78 \times 10^{-4}$ \\
$\mathrm{SO}_{4}{ }^{2-}$ & $8.11 \times 10^{-4}$ \\
$\mathrm{CO}_{3}{ }^{2-}$ & $4.17 \times 10^{-3}$ \\
\hline
\end{tabular}

Solution-treated plates were aged at $673 \mathrm{~K}$ for $86.4 \mathrm{ks}$. Each heat treatment was conducted in an argon atmosphere. Immediately after heating, the plates were quenched into a water bath. Specimens $(2 \mathrm{~mm}$ in thickness and $12 \mathrm{~mm}$ in diameter) were prepared from $2.5 \mathrm{~mm}$-thick plates with machining. These specimens were finally polished with \#600 SiC paper and buffed.

Hanks' solution consisting of only inorganic ions was employed as an electrolyte. The composition of Hanks' solution is similar to that of body fluid, as summarized in Table 2. The electrolyte was deaerated with bubbling $\mathrm{N}_{2}$ gas at a rate of $8.3 \times 10^{-7} \mathrm{~m}^{3} \mathrm{~s}^{-1}$ for $3.6 \times 10^{3} \mathrm{~s}$ and kept at $310 \mathrm{~K}$. Three electrode-type electrolytic cells with a saturated calomel electrode (SCE) as a reference electrode and a platinum plate as a counter electrode were employed. The specimen was immersed in the electrolyte for $1.8 \times 10^{3} \mathrm{~s}$ to allow its open-circuit potential $\left(E_{\text {open }}\right)$ to be stabilized. Subsequently, the potential of the specimen was anodically swept from $E_{\text {open }}$ at a rate of $3.33 \times 10^{-1} \mathrm{mV} \mathrm{s}^{-1}$. The sweep was stopped at 1 and $3 \mathrm{~V} v s$. SCE, followed by rinsing in deionized water and storing in an auto-dry desiccator. Passivity appeared from $E_{\text {open }}$ to $3.7 \mathrm{~V}$, but a small active region at $1.7 \mathrm{~V}$ was observed in the previous study. ${ }^{9}$ "Therefore, surface oxides formed at passive regions before and after the active region were prepared.

\subsection{XPS}

XPS was performed with an electron spectrometer (SSI, SSX100). All binding energies given in this paper are relative to the Fermi level, and all spectra were excited with the monochromatized $\mathrm{Al} \mathrm{K} \alpha$ line $(1486.61 \mathrm{eV})$. The spectrometer was calibrated against $\mathrm{Au} 4 \mathrm{f}_{7 / 2}$ (binding energy, $84.07 \mathrm{eV})$ and $\mathrm{Au} 4 \mathrm{f}_{5 / 2}(87.74 \mathrm{eV})$ of pure gold and $\mathrm{Cu} 2 \mathrm{p}_{3 / 2}$ (932.53 eV), Cu 2 $\mathrm{p}_{1 / 2}(952.35 \mathrm{eV})$, and $\mathrm{Cu}$ Auger $\mathrm{L}_{3} \mathrm{M}_{4,5^{-}}$ $\mathrm{M}_{4,5}$ line (kinetic energy, $918.65 \mathrm{eV}$ ) of pure copper. The energy values were based on published data. ${ }^{10)}$ The take-off angle for photoelectron detection was $35^{\circ}$ from the surface of the specimen. The composition and thickness of the surface oxide were estimated according to the methods of Asami et $a^{11,12)}$ Empirical $^{13-16)}$ and theoretically calculated ${ }^{17)}$ data of the relative photoionization cross-sections were used for the quantification. The relative photoionization cross-sections
Table 3 Photoionization cross-sections of level $j$ of element $i$ relative to that of the $\mathrm{O} 1 \mathrm{~s}, \sigma_{i j} / \sigma_{\mathrm{O} 1 \mathrm{~s}}$.

\begin{tabular}{|c|c|c|c|c|c|c|c|}
\hline Level & $\operatorname{Ti} 2 \mathrm{p}_{3 / 2}$ & $\begin{array}{c}\mathrm{Fe} 2 \mathrm{p}_{3 / 2} \\
\text { (Metal) }\end{array}$ & $\begin{array}{c}\mathrm{Fe} 2 \mathrm{p}_{3 / 2} \\
\text { (Oxide) }\end{array}$ & $\operatorname{Ta} 4 f_{7 / 2}$ & $\mathrm{Zr} 3 \mathrm{~d}_{5 / 2}$ & $\mathrm{Ca} 2 \mathrm{p}$ & P $2 p$ \\
\hline$\sigma_{i j}$ & 1.28 & 2.46 & 1.45 & 2.62 & 2.4 & 2.59 & 2.6 \\
\hline Reference & 13) & 11) & 11) & 14) & 17) & 15) & 16) \\
\hline
\end{tabular}

Table 4 Relative sensitivity factors used for quantification in AES. ${ }^{18)}$

\begin{tabular}{cccccccc}
\hline $\mathrm{C}$ & $\mathrm{Ti}$ & $\mathrm{Fe}$ & $\mathrm{Ta}$ & $\mathrm{Zr}$ & $\mathrm{Ca}$ & $\mathrm{P}$ & $\mathrm{O}$ \\
KLL & LMM & LMM & MNN & MNN & LMM & LMM & KLL \\
\hline 0.105 & 0.35 & 0.24 & 0.085 & 0.23 & 0.92 & 0.32 & 0.195 \\
\hline
\end{tabular}

used in this study are summarized in Table 3 , where $\sigma_{i j} / \sigma_{\mathrm{O} 1 \mathrm{~s}}$ represents the relative photoionization cross-section of a level $j$ electron of an element $i$ to that of $\mathrm{O} 1$ s electrons. An angle-resolved technique for XPS was also applied.

\subsection{AES}

Depth profiles of elements in specimens were obtained by AES using a JEOL, JAMP-7100 electron spectrometer in combination with argon-ion-sputter etching. The vacuum level of the analyzing chamber during measurement was of the order of $10^{-7}-10^{-8} \mathrm{~Pa}$. The accelerating voltage of the primary electrons for the Auger electron excitation was $10 \mathrm{kV}$. The electron probe size was about $1.2 \mu \mathrm{m}$ in diameter, and the current was $5 \times 10^{-7} \mathrm{~A}$. The differential Auger electron spectra were measured, and their peak-to-peak $(\mathrm{p}-\mathrm{p})$ intensities were used for quantification. The modulation voltage for the differential spectra was $5 \mathrm{eVp}-\mathrm{p}$. The $\mathrm{KL}_{2,3} \mathrm{~L}_{2,3}$ transition peaks for carbon, nitrogen, and oxygen, the $\mathrm{L}_{2} \mathrm{M}_{2,3} \mathrm{M}_{2,3}$ peak for calcium, and the $\mathrm{L}_{3} \mathrm{M}_{2,3} \mathrm{M}_{4,5}$ peaks for titanium were used for the analysis under the applied argon-ion-sputter conditions $\left(3 \mathrm{kV}\right.$ and $30 \mathrm{~mA} \mathrm{~cm}^{-2}$ in $8 \times$ $\left.10^{-2} \mathrm{~Pa}\right)$. The quantification was performed using the relative-sensitivity factors summarized in Table $4 .{ }^{18)}$ The concentration of element $i, X_{i}$, was calculated according to the following conventional equation:

$$
X_{i}=\left(I_{i} / \alpha_{i}\right) / \sum_{j=1}^{\mathrm{N}}\left(I_{j} / \alpha_{j}\right)
$$

where $I$ and $\alpha$ are the $\mathrm{p}-\mathrm{p}$ intensity of the Auger peaks and the relative sensitivity factor for the above-mentioned transition for an element, respectively, $i$ and $j$ indicate elements $i$ and $j$, respectively, and $\mathrm{N}$ is the number of elements.

\section{Results and Discussion}

\subsection{Composition of surface oxide}

Carbon was detected on all specimens. From the C 1s spectra, it was concluded that none of the specimens contained carbonate because no peak was detected at an energy region of 289-290 eV, where carbonate should give a C 1s peak. ${ }^{19)}$ Therefore, carbon detected by XPS can be ascribed to so-called contaminant carbon.

XPS spectra of the binding energy regions of Ti 2p, Fe 2p, $\mathrm{Ta} 4 \mathrm{f}$, and $\mathrm{Zr} 3 \mathrm{~d}$ electrons obtained from an untreated 

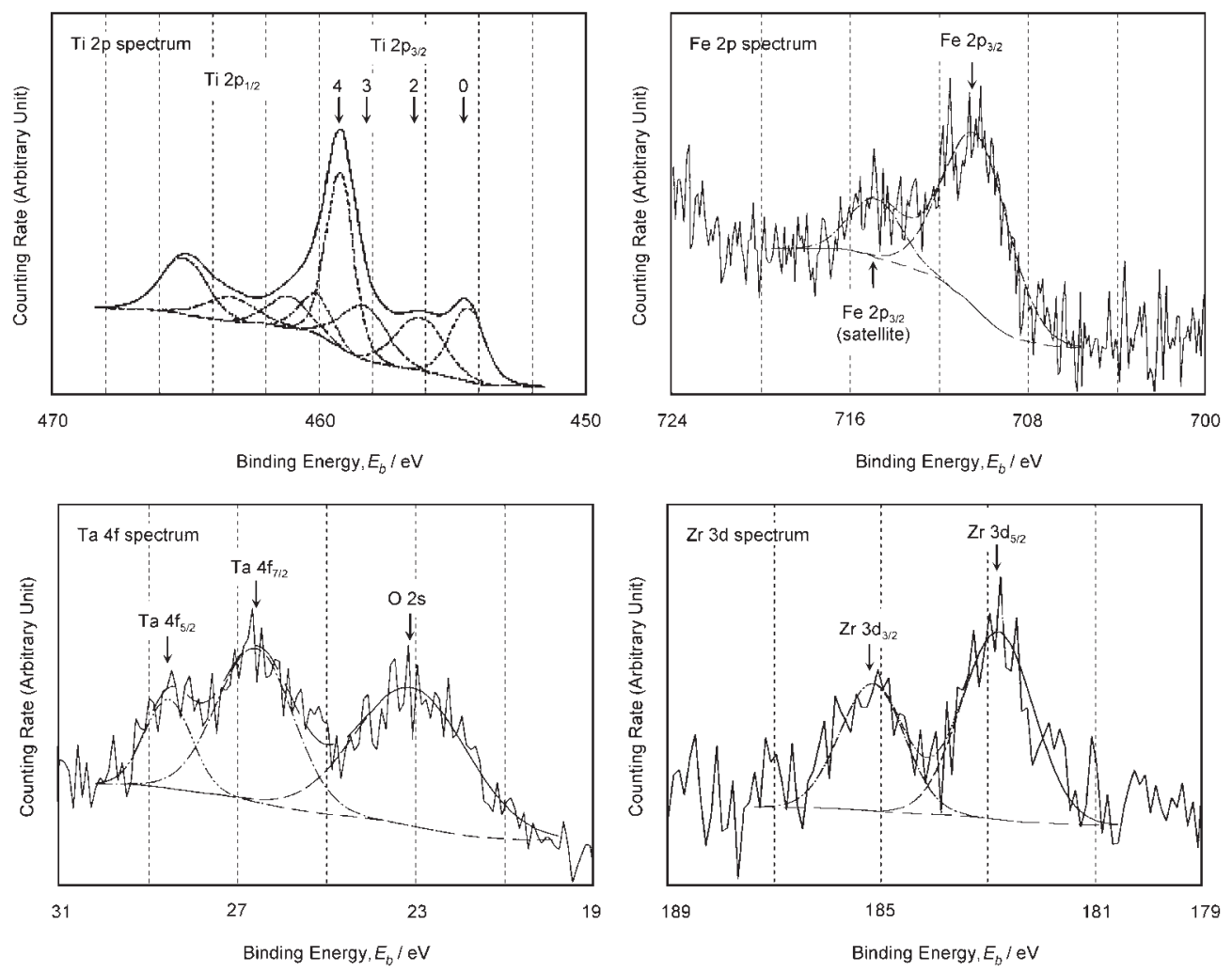

Fig. 1 Typical Ti 2p, Fe 2p, Ta 4f, and Zr 3d spectrums obtained from non-treated specimens.

specimen are shown in Fig. 1. The spectrum of the Ti $2 p$ region was the only one that showed both metallic and oxide states; ${ }^{20)}$ the spectra of regions of other elements originated exclusively from oxide states. ${ }^{21,22)}$ In the oxide, titanium existed as $\mathrm{Ti}^{4+}$ after polarization, iron, as $\mathrm{Fe}^{2+}$, tantalum, as $\mathrm{Ta}^{5+}$, and zirconium, as $\mathrm{Zr}^{4+} \cdot \mathrm{Ti}^{2+}$ and $\mathrm{Ti}^{3+}$ were also detected in an unpolarized specimen. On the other hand, metallic titanium concentrated just under the oxide film because only titanium was detected in a metallic state. Another possibility is that no other metallic elements were detected because the concentrations were under the detection limit of $c a .0 .1 \mathrm{~mol} \%$. In polarized specimens, no metallic state was observed in the $\mathrm{Ti} 2 \mathrm{p}$ region spectrum either, indicating that the surface oxide film grows with anodic polarization.

Calcium and phosphorus were detected on both polarized specimens. The binding energy of $\mathrm{Ca} 2 \mathrm{p}_{3 / 2}$ electrons was $347.3-347.6 \mathrm{eV}$, and that of $\mathrm{P} 2 \mathrm{p}$ electrons was 133.3$133.5 \mathrm{eV}$, indicating that calcium exists as $\mathrm{Ca}^{2+}$ and phosphorus, as $\mathrm{HPO}_{4}{ }^{2-}$ or $\mathrm{PO}_{4}{ }^{3-} .^{23,24)}$ In other words, calcium phosphate was formed. This result is very similar to that obtained through calcium phosphate precipitation on titanium and titanium alloys in Hanks' solution. ${ }^{23-27)}$

The XPS spectrum of the $\mathrm{O} 1 \mathrm{~s}$ electron binding energy region consists of at least three peaks originating from $\mathrm{O}^{2-}$, hydroxide or hydroxyl groups, $\mathrm{OH}^{-}$, and hydrate and/or adsorbed water, as shown in Fig. $2{ }^{28)}$ The proportion of each oxygen state and the ratios of $\left[\mathrm{OH}^{-}\right] /\left[\mathrm{O}^{2-}\right]$ and $\left(\left[\mathrm{OH}^{-}\right]+\right.$ $\left.\left[\mathrm{H}_{2} \mathrm{O}\right]\right) /\left[\mathrm{O}^{2-}\right]$ in the surface oxide film before and after polarization are summarized in Table 5. Surface oxide contained a large amount of $\mathrm{OH}^{-}$. The $\left[\mathrm{OH}^{-}\right] /\left[\mathrm{O}^{2-}\right]$ ratio

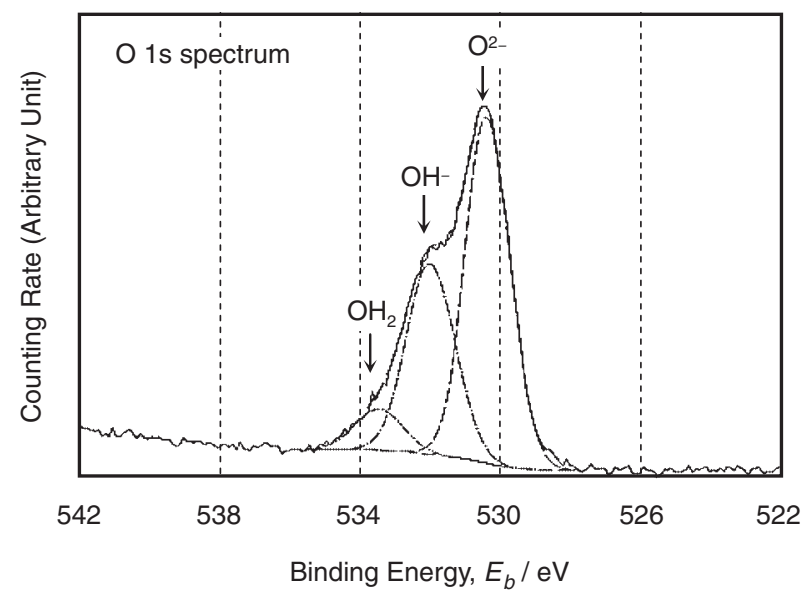

Fig. 2 Typical $\mathrm{O}$ 1s spectrum obtained from metal surface and decomposed into $\mathrm{O}^{2-}, \mathrm{OH}^{-}$, and $\mathrm{H}_{2} \mathrm{O}$ components.

Table 5 Proportion of each oxygen state and ratios of $\left[\mathrm{OH}^{-}\right] /\left[\mathrm{O}^{2-}\right]$ and $\left(\left[\mathrm{OH}^{-}\right]+\left[\mathrm{H}_{2} \mathrm{O}\right]\right) /\left[\mathrm{O}^{2-}\right]$ in the surface oxide film before and after polarization.

\begin{tabular}{lcccc}
\hline & $\mathrm{O}^{2-}$ & $\mathrm{OH}^{-}$ & $\mathrm{H}_{2} \mathrm{O}$ & {$\left[\mathrm{OH}^{-}\right] /\left[\mathrm{O}^{2-}\right]$} \\
\hline Unpolarized & 0.43 & 0.39 & 0.18 & 0.89 \\
1 V polarized & 0.55 & 0.30 & 0.15 & 0.54 \\
3 V polarized & 0.51 & 0.36 & 0.13 & 0.71 \\
\hline
\end{tabular}

decreased with polarization. Dehydration and oxidation proceeded by polarization and resulted in an increase in $\left[\mathrm{O}^{2-}\right]$ and a decrease in $\left[\mathrm{OH}^{-}\right]$. The increase in the ratio by polarization at $3 \mathrm{~V}$ was caused by the precipitation of calcium 
Table 6 Compositions of the surface oxides of unpolarized and polarized specimens and chemical compositions recalculated on the basis of the titanium concentration.

\begin{tabular}{|c|c|c|c|c|c|c|c|c|}
\hline & \multicolumn{7}{|c|}{ Relative concentration (at\%) } & \multirow{2}{*}{$\begin{array}{l}\text { Film thickness } \\
(\mathrm{nm})\end{array}$} \\
\hline & $\mathrm{Ti}$ & $\mathrm{Fe}$ & $\mathrm{Ta}$ & $\mathrm{Zr}$ & $\mathrm{O}$ & $\mathrm{Ca}$ & $\mathrm{P}$ & \\
\hline Unpolarized & 15.1 & 9.7 & 0.4 & 0.5 & 74.4 & 0.0 & 0.0 & 4.8 \\
\hline 1 V Polarized & 18.6 & 5.4 & 0.6 & 0.6 & 68.9 & 3.7 & 2.7 & - \\
\hline 3 V Polarized & 17.8 & 7.7 & 0.4 & 0.7 & 69.5 & 1.4 & 3.0 & - \\
\hline \multicolumn{9}{|c|}{$\begin{array}{l}\text { Unpolarized: } \mathrm{TiFe}_{0.64} \mathrm{Ta}_{0.03} \mathrm{Zr}_{0.03} \mathrm{O}_{2.11}(\mathrm{OH})_{1.91} \cdot 0.88 \mathrm{H}_{2} \mathrm{O} \\
1 \mathrm{~V} \text { Polarized: } \mathrm{TiFe}_{0.29} \mathrm{Ta}_{0.03} \mathrm{Zr}_{0.03} \mathrm{O}_{2.04}(\mathrm{OH})_{1.11} \cdot 0.55 \mathrm{H}_{2} \mathrm{O} \\
3 \mathrm{~V} \text { Polarized: } \mathrm{TiFe}_{0.43} \mathrm{Ta}_{0.02} \mathrm{Zr}_{0.04} \mathrm{O}_{1.99}(\mathrm{OH})_{1.41} \cdot 0.51 \mathrm{H}_{2} \mathrm{O}\end{array}$} \\
\hline
\end{tabular}

phosphate. When calcium phosphate was precipitated, the ratio increased. ${ }^{29)}$

The compositions of the surface oxides of unpolarized and polarized specimens are summarized in Table 6. Table 6 contains the chemical compositions recalculated on the basis of the titanium concentration. After polarization, titanium increased, while iron decreased. The oxidation of titanium proceeded, and iron may have been dissolved during polarization. With $3 \mathrm{~V}$ polarization, iron again increased. After passing the slight active region on the polarization curve, iron concentrated in the oxide film. Zirconium seemed to increase with polarization.

The thickness of the surface oxide in the unpolarized specimen was calculated as $4.8 \mathrm{~nm}$ (Table 6), i.e., the same as those of cp-Ti and other titanium alloys. ${ }^{29)}$ After polarization, the thickness could not be calculated because no metallic state was detected.

\subsection{Depth profiles of the surface oxide}

The AES depth profiles of the relative concentrations of elements in the surface region before and after polarization are shown in Fig. 3. An oxygen-concentrated and titaniumdepleted layer existed inside the surface oxide film in the unpolished specimen. After polarization, this layer expanded with the increase of the polarization potential. The titanium hyper-oxidized layer was generated by polarization. This layer contained a low concentration of iron and worked as a corrosion protective layer. Iron is contained the surface oxide layer and oxygen atoms are more attractive to titanium atoms according to a larger activation energy of titanium, followed by the dissolution of iron. Subsequently, oxygen-rich titanium oxide layer with low iron concentration remains. Attraction of oxygen to zirconium atom is observed in a Ti$\mathrm{Zr}$ binary alloy. ${ }^{30)}$ In general, the surface oxide layer of $\mathrm{cp}-\mathrm{Ti}$ and Ti-6Al-4V after polarization does not have this oxygenrich layer in the range of its passivation. During anodic polarization, the surface oxide of titanium grows, however the composition gradually changes from the outmost layer to inside layer and does not contain the above oxygen-rich layer.

Dissolution of iron also occurred during polarization, and dissolution occurred from both the oxide layer and the alloy substrate. The slight active region on the polarization curve may have been caused by the dissolution of iron.

Both titanium and iron were depleted in the hyper-oxidized layer in the unpolarized specimen; on the other hand, in the $1 \mathrm{~V}$ polarization specimen, titanium was depleted, and iron

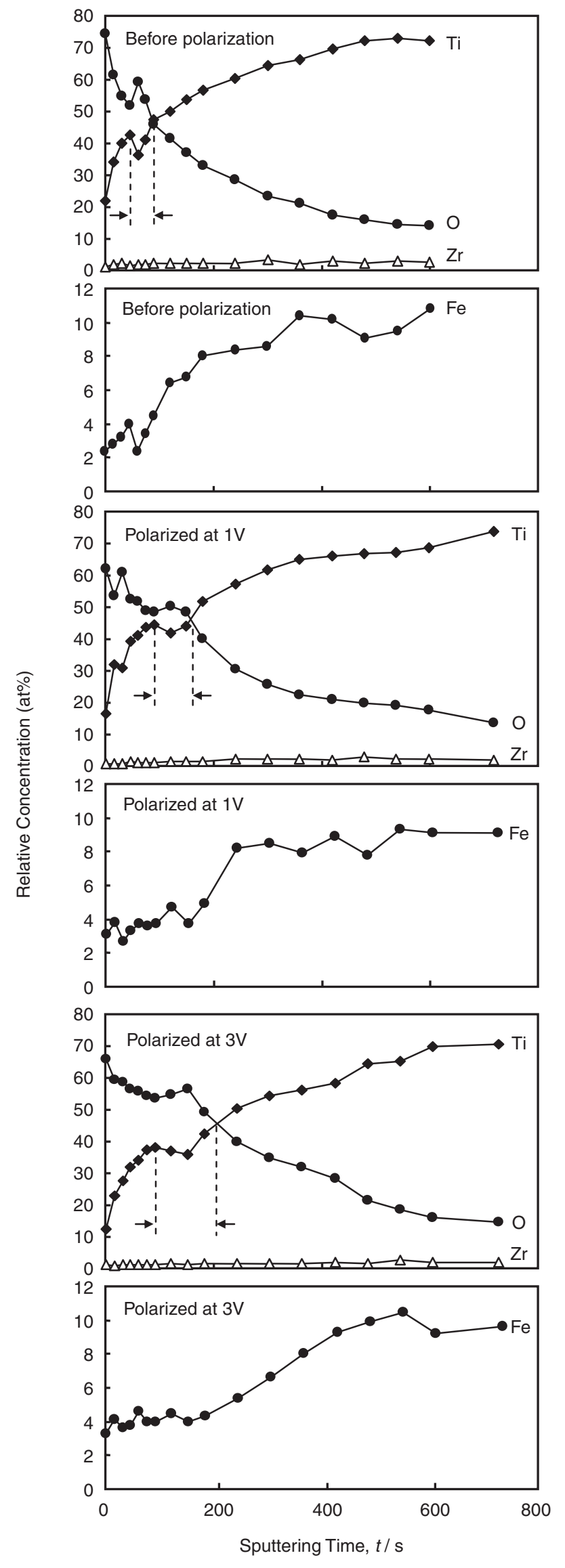

Fig. 3 Depth profiles of titanium, iron, zirconium, and oxygen in $\mathrm{Ti}-8 \mathrm{Fe}-$ $8 \mathrm{Ta}-4 \mathrm{Zr}$ in mass\% (Ti-7.5Fe-2.3Ta-2.3Zr in at $\%)$ before and after polarization in Hanks' solution. 
was enriched. After polarization at $3 \mathrm{~V}$, titanium was slightly depleted, while iron did not change. Therefore, the slight active region on the polarization curve may also have been caused by the dissolution of titanium in addition to that of iron.

The depth profiles of other elements, such as tantalum and zirconium, were almost constant before and after polarization, and no relationship to the hyper-oxidized layer above was found.

\section{Conclusions}

The surface oxide films on $\mathrm{Ti}-8 \mathrm{Fe}-8 \mathrm{Ta}-4 \mathrm{Zr}$ after anodic polarization at 1 and $3 \mathrm{~V}$ in Hanks' solution were characterized using XPS and AES to elucidate the high corrosion resistance mechanism of the alloy in Hanks' solution and the following conclusions are obtained.

(1) The surface oxide film on $\mathrm{Ti}-8 \mathrm{Fe}-8 \mathrm{Ta}-4 \mathrm{Zr}$ is grown with anodic polarization.

(2) Calcium phosphate was formed on the alloys after polarization.

(3) Dehydration and oxidation proceeds by polarization and resulted in an increase in $\left[\mathrm{O}^{2-}\right]$ and a decrease in $\left[\mathrm{OH}^{-}\right]$.

(4) After polarization, titanium increased, and iron decreased in the surface oxide film.

(5) Dissolution of iron from both the oxide layer and the alloy substrate occur during the polarization. The slight active region on the polarization curve may have been caused by the dissolution of iron.

(6) Oxygen-rich titanium oxide layer with low iron concentration is formed and the layer grows after polarization. This layer may works as a corrosionprotective layer.

\section{Acknowledgements}

We would like to thank Mr. Syuji Kuroda, Mr. Masaki Kobayashi, and Ms. Sanae Sugita for their valuable support during the experiments.

\section{REFERENCES}

1) J. A. Davidson and P. Kovacs: U.S. Patent 5169597.

2) T. Ahmed, M. Long, J. Silvetri, C. Ruiz and H. J. Rack: Titanium '95, (The Institute for Materials, 1996), pp. 1760-1767.

3) D. Kuroda, M. Niinomi, M. Morinaga, Y. Kato and T. Yashiro: Mater. Sci. Eng. A 243 (1998) 244-249.

4) Y. Song, D. S. Xu, R. Yang, D. Li, W. T. Wu and Z. X. Guo: Mater. Sci. Eng. A 260 (1999) 269-274.

5) M. Ikeda, K. Inoue, S. Komatsu, T. Sugimoto and K. Kamei: Tetsu-toHagane 84 (1998) 206-211.

6) M. Ikeda, S. Komatsu, T. Sugimoto, S. Kamei and K. Inoue: Tetsu-toHagane 84 (1998) 790-796.

7) H. Fujii, S. Soeda, M. Hanaki and H. Okano: Titanium '95, (The Institute for Materials, 1996), pp. 2309-2316.

8) A. Bhattacharjee, V. A. Joshi and A. K. Gogia: Titanium '99, (CRISM "Prometey" 2000), pp. 537-548.

9) D. Kuroda, H. Kawasaki, A. Yamamoto, S. Hiromoto and T. Hanawa: Mater. Sci. Eng. C 25 (2005) 312-320.

10) K. Asami: J. Electron Spectrosc. 9 (1976) 469-478.

11) K. Asami, K. Hashimoto and S. Shimodaira: Corros. Sci. 17 (1977) $713-723$.

12) K. Asami and K. Hashimoto: Corros. Sci. 24 (1984) 83-97.

13) K. Asami, S.-C. Chen, H. Habazaki, A. Kawashima and K. Hashimoto: Corros. Sci. 31 (1990) 727-732.

14) J. H. Kim, H. Yoshioka, H. Habazaki, A. Kawashima, K. Asami and K. Hashimoto: Corros. Sci. 33 (1992) 1507-1518.

15) K. Asami, M. S. De Sá and V. Ashworth: Proc. 6th European Symposium on Corrosion Behavior of Amorphous $\mathrm{Ni}-\mathrm{Cr}-\mathrm{P}-\mathrm{B}$ Alloys (1985) pp. 769-778.

16) K. Hashimoto, M. Kasaya, K. Asami and T. Masumoto: Corros. Eng. 26 (1977) 445-452.

17) J. H. Scofield: J. Electron. Spectrosc. 8 (1976) 129-137.

18) R. Shimizu and K. Yoshihara: Jitsuyo Ohje Denshibunkoho, (Kyoritsu Shuppan, Tokyo, Japan, 1989), p. 222.

19) J. S. Hammond, J. W. Holubka, J. E. DeVries and R. A. Dickie: Corros. Sci. 21 (1981) 239-253.

20) K. Asami, S.-C. Chen, H. Habazaki and K. Hashimoto: Corros. Sci. 35 (1993) 43-49.

21) C. D. Wagner, W. M. Riggs, L. E. Davies, J. F. Moulder and G. E. Muilenberg: Handbook of X-ray Photoelectron Spectroscopy (PerkinElmer, Eden Prairie, MN, 1979) p. 74, p. 80.

22) C. D. Wagner: Practical Surface Analysis, 2nd ed, Vol. 1, Eds. D. Briggs and M. P. Seah (Wiley, New York, 1990) App. 5, pp. 595-634.

23) T. Hanawa and M. Ota: Biomaterials 12 (1991) 767-774.

24) T. Hanawa and M. Ota: Appl. Surf. Sci. 55 (1992) 269-276.

25) J. L. Ong, L. C. Lucas, G. N. Raikar, R. Connatser and J. C. Gregory: J. Mater. Sci. Mater. Med. 6 (1995) 113-119.

26) P. Li and P. Ducheyne: J. Bomed. Mater. Res. 41 (1998) 341-348.

27) T. Hanawa, S. Hiromoto, K. Asami, O. Okuno and K. Asaoka: Mater. Trans. 43 (2002) 3000-3004.

28) K. Asami and K. Hashimoto: Corros. Sci. 17 (1977) 559-570.

29) S. Hiromoto, T. Hanawa and K. Asami: Biomaterials 25 (2004) 979986.

30) T. Hanawa, O. Okuno and H. Hamanaka: J. Jpn. Inst. Met. 10 (1992) 1168-1173. 